\title{
Effect of sodium chloride deficiency on basal metabolism in broiler chickens
}

\author{
By ELŻBIETA WALICKA, R. RYŚ, J. KORELESKI AND M. PIETRAS \\ Department of Animal Nutrition, Institute of Zootechnics, \\ 3I-047 Kraków, Sarego 2, Poland
}

(Received 23 January 1979 - Accepted 2 I June 1979)

\begin{abstract}
I. Male broiler chickens were given a sodium chloride-deficient or $\mathrm{NaCl}$-adequate diet from 7 to 2I $\mathrm{d}$ of age in Expt $\mathrm{I}$ and 28 to $56 \mathrm{~d}$ of age in Expt 2.

2. NaCl-deficient chickens had a markedly poorer growth and food conversion efficiency than those given the $\mathrm{NaCl}$-adequate diet.

3. $\mathrm{NaCl}$ deficiency was associated with an increase in basal metabolic rate and increases in oxygen consumption, heat production and respiratory quotients were also noted. The glycogen content of chicken livers was also higher.

4. Measurements of acid-base balance were found to be changed in NaCl-deficient chickens. Values for $\mathrm{pH}$ and bicarbonate content in blood plasma were lowered.

5. $\mathrm{NaCl}$ deficiency increased the packed cell volume and thyroxine level in blood plasma. Sodium and chloride contents in blood were lowered.

6. Results are discussed in relation to the decreased food conversion in $\mathrm{NaCl}$-deficient chickens.
\end{abstract}

A deficiency of dietary sodium chloride causes growth retardation accompanied by a reduction in food conversion in chickens (Burns et al. 1953; Summers et al. 1967; Nott \& Combs, I969; Dewar \& Whitehead, 1973; Ryś et al. 1975; Ross, 1977). NaCl-deficient chickens had a lower plasma sodium content and hypertrophy of adrenal gland (Lumijarvi et al. I966) and histological changes in kidneys (Siegel, I96I), while turkeys had kidney hypertrophy (Leeson et al. 1976a). A raised packed-cell volume in deficient chickens could suggest dehydration of the body (Lumijarvi et al. 1966). Considering the chicken's requirement for dietary chloride is nearly $50 \%$ lower than that for sodium, it could be suggested that the reduction in performance in chickens is attributable to $\mathrm{Na}$ rather than $\mathrm{Cl}^{-}$deficiency (Burns et al. 1953; Summers et al. 1967). Hurwitz et al. (1973) found decrease in blood $\mathrm{pH}$ in $\mathrm{Na}$-deficient chickens. In a previous study we showed that the modification of carbohydrate digestion produced by $\mathrm{NaCl}$ deficiency did not appear to be the main factor responsible for the decreased performance of $\mathrm{NaCl}$-deficient chicks (Koreleski et al. 1976). The mechanism of the increased food expenditure for weight gain in $\mathrm{Na}$-deficient chickens was not elucidated.

In the present study the effect of $\mathrm{NaCl}$ deficiency on the basal metabolic rate, plasma thyroxine level and measurements of acid-base balance in chickens were investigated.

\section{EXPERIMENTAL}

Two experiments, each using forty male broiler chickens (Cornish $\times$ White Rock) were carried out at from 7 to $2 \mathrm{I}$ d of age (Expt I) and 28 to $56 \mathrm{~d}$ of age (Expt 2). Chickens were given standard starter mixture before the trial. During the experimental periods they were given a basal soya-bean diet (Table I) either supplemented with $3 \mathrm{~g} \mathrm{NaCl} / \mathrm{kg}$ (control group) or unsupplemented (deficient group) when the diet contained only $0 \cdot 18 \mathrm{~g} \mathrm{NaCl} / \mathrm{kg}$.

In both experiments control or deficient diets were offered to groups of twenty individually fed chickens. Broilers were housed in separate cages with screen floors. Food and distilled 
Table I. Composition $(\mathrm{g} / \mathrm{kg})$ of the basal low-sodium chloride diet

\begin{tabular}{|c|c|}
\hline \multicolumn{2}{|l|}{ Component } \\
\hline Soya-bean oil meal & $36 \cdot 0$ \\
\hline Maize meal & $58 \cdot 4$ \\
\hline Beef tallow & 3.0 \\
\hline $\begin{array}{l}\text { Standard vitamin-mineral-antibiotic premix } \\
\text { (free of } \mathrm{NaCl} \text { ) }\end{array}$ & $I \cdot 0$ \\
\hline Dicalcium phosphate & $\mathrm{I} \cdot \mathrm{O}$ \\
\hline Limestone & 0.5 \\
\hline DL-methionine & 0.1 \\
\hline \multicolumn{2}{|l|}{ Analysis } \\
\hline Crude protein (nitrogen $\times 6.25$ ) & $212 \cdot 3$ \\
\hline Diethyl ether extract & $64 \cdot 6$ \\
\hline Crude fibre & $40 \cdot 0$ \\
\hline Metabolizable energy MJ (kcal) & $12.8 \quad(3060)$ \\
\hline
\end{tabular}

water were given ad lib. The weight gains and food conversion efficiency (g weight gain/g food intake) were recorded weekly.

Expt I. For the determination of acid-base measurements on the $14^{\text {th }}$ day of the experiment (2 I d of age) blood samples were collected from eight randomly chosen cockerels per treatment. Blood was taken anaerobically from the wing vein into a heparinized glass capillary and maintained at $4-8^{\circ}$. Estimations of $\mathrm{pH}$ and partial pressure of carbon dioxide $\left(\mathrm{pCO}_{2}\right)$ were made using a Micro-Astrup AME-I Radiometer. The bicarbonate content was calculated using the Hasselbach-Henderson equation, assuming a pK value of 6.09 and the solubility of carbon dioxide in water at $41 \cdot 5^{\circ}$ to be 0.0278 (Helbacka et al. 1964). A blood sample was also taken into microcapillaries and centrifuged for $10 \mathrm{~min}$ at $3000 \mathrm{~g}$ for determination of packed cell volume. At the same time basal metabolic rate was estimated in eight chickens from each group, which had live weights nearest to the average weight of the group. Chickens were fasted for $12-18 \mathrm{~h}$ with free access to distilled water, weighed and subjected to a period of adaptation, when they were maintained for $15 \mathrm{~min}$ in the dark at a neutral temperature $\left(29^{\circ}\right)$. The volume of oxygen consumed and $\mathrm{CO}_{2}$ expired in a $30 \mathrm{~min}$ period were measured using a Kipp-Zonen MG-4 diaferometer. Respiratory quotient $\mathrm{RQ}$ and heat production were estimated. Heat production (not corrected for nitrogen catabolism) calculated for a $24 \mathrm{~h}$ period was expressed in $\mathrm{J} / \mathrm{kg}$ body-weight or metabolic body-weight (body-weight ${ }^{0.75}$ ).

On the day after basal metabolism estimation the chickens were killed and blood collected in heparinized test-tubes and centrifuged. Samples of plasma were stored in the cold $\left(-20^{\circ}\right)$ and then analysed for $\mathrm{Na}$ and $\mathrm{Cl}^{-}$content.

Expt 2. At $56 \mathrm{~d}$ of age (after the $28 \mathrm{~d}$ of the experimental period) eight chickens were chosen from each group for basal metabolism estimations having live weights near to the average weight of the group as described for Expt I. After estimations of basal metabolism chickens were killed and blood collected. Plasma was stored at $-20^{\circ}$ and then analysed for thyroxine content. Immediately after killing, the livers were removed, frozen in liquid $\mathrm{N}_{2}$ and stored at $-20^{\circ}$ until analysed for glycogen content.

Analytical methods. Basal nutrient content of the diet was estimated as described by Skulmowski (1964). The levels of $\mathrm{Na}$ in the food and in blood plasma were analysed using a flame photometric method and $\mathrm{Cl}^{-}$using the titration method with silver nitrate (Ostrowski, 1974). Thyroxine content in plasma was analysed using a competitive-proteinbinding technique (Murphy, I 965). Glycogen in liver was estimated using a colorimetric method (Stefaniak, 1964).

Statistical analysis. The significance of differences between the two treatments was examined by Student's $t$ test. 


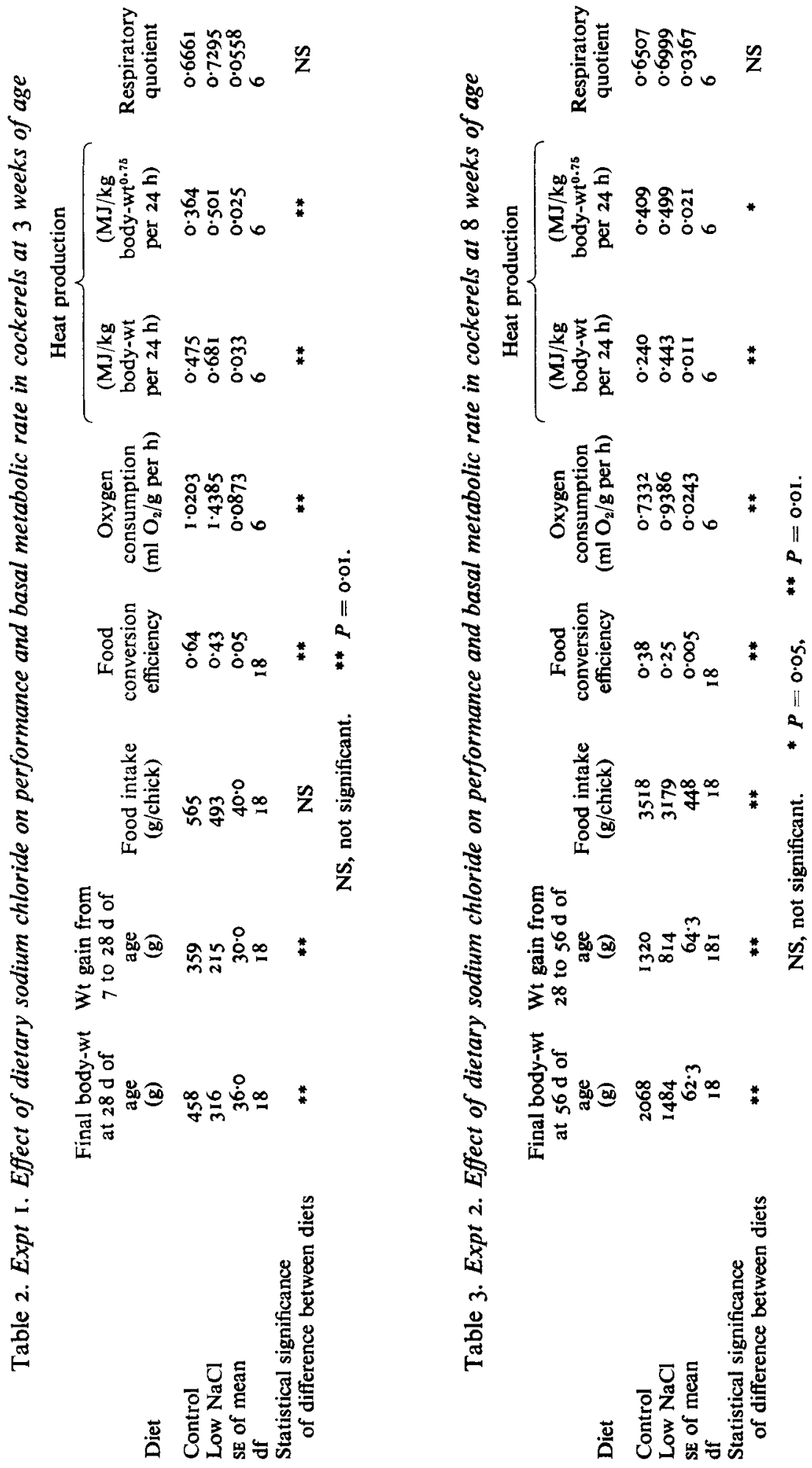


Table 4. Expt I. Effect of dietary sodium chloride on the blood acid-base measurements and packed cell volume and the level of sodium and chloride in the plasma of chickens

\begin{tabular}{|c|c|c|c|c|c|c|}
\hline Diet & $\mathrm{pH}$ & $\begin{array}{c}\text { Partial } \\
\text { pressure of } \\
\text { carbon dioxide } \\
(\mathrm{mmHg})\end{array}$ & $\begin{array}{c}\text { Bicarbonate } \\
(\mathrm{mol} / \mathrm{l})\end{array}$ & $\begin{array}{c}\text { Sodium } \\
(\mathrm{mol} / \mathrm{l})\end{array}$ & $\begin{array}{l}\text { Chloride } \\
(\mathrm{mol} / \mathrm{l})\end{array}$ & $\begin{array}{l}\text { Packed cell } \\
\text { volume }\end{array}$ \\
\hline Control & $7 \cdot 263$ & 56.08 & 0.023 & 0.186 & 0.152 & 0.29 \\
\hline Low $\mathrm{NaCl}$ & $7 \cdot 193$ & 54.60 & 0.019 & 0.149 & 0.138 & 0.40 \\
\hline SE of mean & 0.024 & 3.06 & 0.001 & 0.013 & 0.002 & 0.01 \\
\hline & I 4 & 14 & I4 & I 4 & 14 & 14 \\
\hline $\begin{array}{l}\text { Statistical significance } \\
\text { of difference between } \\
\text { diets }\end{array}$ & * & NS & ** & * & $* *$ & ** \\
\hline
\end{tabular}

Table 5. Expt 2. Effect of sodium chloride deficiency on the thyroxine level in blood plasma and glycogen content in fresh liver of chickens

\begin{tabular}{|c|c|c|}
\hline Diet & $\begin{array}{c}\text { Thyroxine } \\
(\mu \mathrm{g} / \text { 100 ml plasma })\end{array}$ & $\begin{array}{c}\text { Glycogen } \\
\text { (mg/roog liver) }\end{array}$ \\
\hline $\begin{array}{l}\text { Control } \\
\text { Low } \mathrm{NaCl} \\
\mathrm{sE} \text { of mean } \\
\text { df } \\
\text { Statistical significance }\end{array}$ & $\begin{array}{l}1 \cdot 70 \\
2 \cdot 43 \\
0 \cdot 1157 \\
18\end{array}$ & $\begin{array}{r}7 \cdot 27 \\
14 \cdot 47 \\
1 \cdot 57 \\
18\end{array}$ \\
\hline of difference between diets & ** & $* *$ \\
\hline
\end{tabular}

\section{RESULTS}

Deficiency of $\mathrm{NaCl}$ caused significant growth retardation and decreased food intake and food conversion in chickens of both ages (Tables 2 and 3).

Basal metabolic rate was increased in $\mathrm{NaCl}$-deficient chickens and this effect was not dependent on age. There was a statistically significant increase $(P=0.0 \mathrm{I})$ in $\mathrm{O}_{2}$ consumption and heat production. Differences in RQ were not statistically significant.

$\mathrm{NaCl}$ deficiency in chickens significantly changed acid-base measurements (Table 4 ). Bicarbonate content and $\mathrm{pH}$ values in the blood were lowered $(P=0.05)$, as were $\mathrm{Na}$ and $\mathrm{Cl}^{-}$levels in blood plasma $(P=0.05$ and $P=0.0$ I respectively). Packed cell volume in $\mathrm{NaCl}-$ deficient chickens was significantly increased $(P=0.0 \mathrm{I})$. Deficiency caused a $100 \%$ increase in the glycogen content of the liver (Table 5 ). The level of thyroxine in blood plasma was also increased $(P=0.0 \mathrm{I})$.

\section{DISCUSSION}

Results of both experiments were similar to published results and showed depressed performance in chickens given the $\mathrm{NaCl}$-deficient diet. It seems that some of the effects recorded for $\mathrm{NaCl}$-deficient birds resulted from reduced food intake, which was of the order of $12 \%$. Lower food intake, however, could not be the main reason for the marked food conversion and growth depression (by about 33.5 and $39 \%$, respectively) as it was found in the experiments. Apart from the latter finding, dietary $\mathrm{NaCl}$ deficiency affected the body water metabolism. As the result of an imbalance in osmotically active $\mathrm{Na}$ and $\mathrm{Cl}^{-}$ions it 
was suggested that there was movement of water from extra- to intracellular fluids. The translocation of water could have caused body dehydration in chickens, as suggested by Tosteson \& Hoffman (1960). These changes resulted in increased packed cell volume and an imbalance in the acid-base equilibrium.

A similar result was reported by Lumijarvi et al. (1966), who found increased values for packed cell volume and a decreased plasma $\mathrm{Na}$ content in $\mathrm{NaCl}$-deficient chickens. Dehydration was noted in spite of increased water intake in $\mathrm{NaCl}$-deficient chickens. These findings suggest that the level of body water may have been one of the reasons for reduced growth in $\mathrm{NaCl}$-deficient chickens. Under conditions of dehydration there is stimulation of some processes for endogenous water synthesis in the body (Leeson et al. 1976b), e.g. lipid metabolism with coupled oxidative phosphorylation in the respiratory chain. Increased lipid catabolism is accompanied by enhanced heat production and $\mathrm{O}_{2}$ consumption, and symptoms of increased heat production were noted in our experiment in the instance of $\mathrm{NaCl}$-deficient chickens. Values for $\mathrm{RQ}$ and increased glycogen accumulation in liver also support this suggestion.

It is known that there is functional interaction between thyroid gland activity and $\mathrm{Na}$ circulation in the body of rats (Fregly \& Taylor, 1964; Taylor \& Fregly, 1964). The Na absorption process in renal tubules requires energy and is related to energy-releasing metabolic reaction; Matty \& Green (1962) observed that in the absence of $\mathrm{Na}$ and presence of thyroxine there is an increased transport of $\mathrm{Na}$ through the cell membrane, accompanied by increased $\mathrm{O}_{2}$ and water consumpticn. It may be suggested that energy requirements are increased in $\mathrm{Na}$-deficiency states and these are accompanied by an increased metabolic rate and a stimulation of thyroid activity. The latter could be the reason for the increased levels of thyroxine observed in the second experiment. It is also possible that higher levels of thyroxine could decouple to some extent oxidative phosphorylation (Slater, 1953; Karlson, I970). From our results it is difficult to ascertain whether the higher levels of thyroxine in blood are the result of increased hormone synthesis or a consequence of blood dehydration. The question could also be raised concerning the extent of decoupling of oxidative phosphorylation under the influence of total thyroxine activity in the body or thyroxine level in blood.

It would seem likely that our hypothesis could explain the decreased food conversion observed in $\mathrm{NaCl}$-deficient chickens.

\section{REFERENCES}

Burns, C. H., Cravens, W. W. \& Phillips, P. H. (1953). J. Nutr. 50, 317.

Dewar, W. A. \& Whitehead, C. C. (1973). Br. Poult. Sci. r4, 315.

Fregly, M. J. \& Taylor, R. E. (1964). Endocrinology 75, 27.

Helbacka, N, V. L., Casterline, J. L., Smith, C. J. \& Shaffner, C. S. (1964). Poult. Sci. 43, 138.

Hurwitz, S., Cohen, L., Bar, A. \& Bornstein, S. (1973). Poult. Sci. 52, 903.

Karlson, P. (1970). Kurzes Lehrbuch der Biochemie für Mediziner und Naturwissenschaftler, vol. 7. Stuttgart, G. Thieme Verlag.

Koreleski, J., Ryś, R. \& Walicka, E. (1976). Archs Geflïgelk. 6, 193.

Leeson, S., Summers, J. D. \& Ferguson, A. E. (1976a). Poult. Sci. 55, 2455.

Leeson, S., Summers, J. D. \& Moran, E. T. Jr. (1976b). Wld Poult. Sci. J. 32, 185.

Lumijarvi, D. H., Koike, T. I. \& Hill, F. W. (1966). Poult. Sci. 45, I 100.

Matty, A. J. \& Green, K. (1962). Life Sci. 9, 487.

Murphy, B. E. P. (1965). J. Lab. clin. Med. 66, 161.

Nott, H. \& Combs, G. F. (1969). Poult. Sci. 48, 660.

Ostrowski, W. (1974). Wybrane metody z chemii klinicznej (Some Methods of Clinical Chemistry).

Warszawa: PZWL.

Ross, E. (1977). Poult. Sci. 56, i 53.

Ryś, R., Koreleski, J. \& Kuchta, M. (1975). Rocz. nauk. Zoot. 2, 181.

Siegel, H. S. (1961). Poult. Sci. 40, 1455.

Skulmowski, J. (1964). Metody badania pasz (Chemical Analysis of Feeds). Warszawa: PWRiL. 
Slater, E. C. (1953). Nature, Lond. 172, 975.

Stefaniak, B. (1964). Polskie Archwm wet. 8, 453.

Summers, J. D., Moran, E. T. \& Pepper, W. F. (1967). Poult. Sci. 46, I 557.

Taylor, R. E. \& Fregly, M. J. (1964). Endocrinology 75, 33.

Tosteson, D. C. \& Hoffman, J. F. (1960). J. gen. Physiol. 44, 169. 